\title{
Ultrastructure of Lycopersicon peruvianum leaf explants and streptomycin-resistant shoots on medium containing streptomycin
}

\author{
Aileen Mary Timmons' \& Philip John Dix* \\ Department of Biology, St. Patrick's College, Maynooth, Co. Kildare, Ireland; ( ${ }^{1}$ present address: \\ Scottish Crop Research Institute, Inergowrie, Dundee DD2 5DA, Scotland UK)( ${ }^{*}$ requests for \\ offprints)
}

Received 24 June 1992; accepted in revised form 20 January 1993

Key words: adventitious shoots, antibiotic resistance, chloroplast mutations, plastid segregation

\section{Abstract}

The effect of streptomycin on morphogenic explants of Lycopersicon peruvianum Mill. was examined microscopically at both the light and ultrastructural level. Early stages in shoot regeneration from leaf explants were distinguished as meristematic tissue at both levels. Small starch grains were observed in the plastids in this tissue but not in plastids in regenerated shoots. In the presence of streptomycin, adventitious shoot regeneration from sensitive leaf strips was inhibited. Large layered bodies were observed within the plastids of sensitive leaf tissue, suggesting the disruption of thylakoid membrane formation. Streptomycin resistant $L$. peruvianum lines, as well as a chlorophyll-deficient line, were also examined microscopically. The chloroplasts of newly regenerated streptomycin resistant shoots contained well developed internal membranes and conspicuous starch grains. Cells containing a mixture of resistant and sensitive plastids were not observed. The plastids in chlorophyll-deficient tissue completely lacked thylakoid membranes, although small vesicles and intraplastid bodies were seen within the stroma.

Abbreviations: NMU - N-methyl-N-nitrosourea

\section{Introduction}

Plastome-encoded resistance to antibiotics has generated much interest as a source of markers for studies on organelle genetics (Medgyesy 1990). Mutants conferring resistance to streptomycin have now been isolated, using in vitro culture methods, in several higher plant species mostly in the Solanaceae (McCabe et al. 1989; Jansen et al. 1990). The most extensively characterised of these are of Nicotiana tabacum L. Resistance is maternally inherited (Maliga et al. $1973,1975)$ and localised to the $16 \mathrm{~S}$ rRNA (Etzold et al. 1987; Fromm et al. 1989) or the
S12 ribosomal protein gene (Galili et al. 1989) of the plastid DNA.

Frequencies for spontaneous plastome mutation to antibiotic resistance are likely to be extremely low, yet resistant mutants have been selected using callus cultures (Maliga et al. 1973) and protoplast-derived colonies (Hamill et al. 1986) without recourse to mutagenic agents. For recent protocols, based on selection in seedlings (Fluhr et al. 1985) or organogenetic explants (McCabe et al. 1989), an efficient plastome targeted mutagen (nitroso-methyl urea) appears to be important. For the latter procedure, leaf strips or discs are incubated with the mutagen 
and then placed on levels of streptomycin causing bleaching and supression of adventitious shoot initiation from sensitive cells. Normal green plants are recovered from resistant cells (McCabe et al. 1989). The procedure works well for several species including Lycopersicon peruvianum Mill. Current investigations are aimed at achieving a fuller understanding of the segregation of small numbers of antibiotic resistant plastome copies, using this leaf strip mutagenesis procedure. This objective, which has practical implications for the routine selection of chloroplast recombinants and transformants, needs to be underpinned by an appreciation of the cytological effects of the antibiotics on the system. The effects of antibiotics on Chlamydomonas (Conde et al. 1975) and on higher plant tissues (Toyama 1972; Maliga et al. 1975; Dix et al. 1977; Zamski \& Umiel 1982) has been examined, but the present study was initiated to extend these investigations to leaf explants during the process of adventitious shoot initiation and development, that is, the conditions under which plastic segregation is normally occurring after leaf disc mutagenesis.

\section{Materials and methods}

Seed of $L$. peruvianum (self-incompatibility genotypes $S_{1} S_{2}$ and $S_{4} S_{5}$ ) were generously provided by $K$. Sree Ramulu. To obtain axenic shoot cultures, seeds were surface sterilised using $10 \%$ domestic bleach ('Domestos') for $10 \mathrm{~min}$, followed by $3 \times 5 \mathrm{~min}$ washes with sterile distilled water, and transferred to the surface of RM medium, consisting of MS (Murashige \& Skoog 1962) salt solution plus $30 \mathrm{~g}^{-1}$ sucrose, pH adjusted to 5.7 and solidified with $7 \mathrm{~g} \mathrm{I}^{-1}$ Difco Bacto-agar, in $9 \mathrm{~cm}$ Petri dishes. These and all other cultures were grown at $25^{\circ} \mathrm{C}$, with an 18-h photoperiod (1,500 lux). Nodal cuttings from the seedlings were transferred to fresh RM medium after 5-6 weeks, and the resulting shoot cultures subcultured in the same way, at 5-6 week intervals. For mutagenesis, leaf strips $(0.2 \times 1 \mathrm{~cm})$ were shaken $(100 \mathrm{rpm}$ on a rotary shaker) with $1 \mathrm{mM} \quad \mathrm{N}$-nitroso-N-methylurea (NMU-Sigma) in liquid RM medium for $120 \mathrm{~min}$, washed and placed on regeneration medium with or without $500 \mathrm{mg} \mathrm{l}^{-1}$ streptomycin sulphate. Details of culture conditions for adventitious shoot regeneration, mutagenesis procedures and safe handling of the mutagen are provided in earlier reports (McCabe et al. 1989, 1990; Dix et al. 1990). Small green nodules (resistant adventitious shoots) were excised from the leaf material as soon as they were visible and fixed immediately in 3\% gluteraldehyde in $0.05 \mathrm{M}$ phosphate buffer ( $\mathrm{pH}$ 6.8). Controls where shoot primordia developing on nonmutagenised explants, on regenerating medium without streptomycin, and non-mutagenised explants on the same medium but containing streptomycin. The samples were post-fixed for $1.5 \mathrm{~h}$ in $2 \%$ osmium tetroxide in $0.05 \mathrm{M}$ phosphate buffer before being passed through an alcohol series $(10,30,50,70,95$ and $100 \%$ alcohol for $10 \mathrm{~min}$ each and $100 \%$ for a further $30 \mathrm{~min}$ ). The tissue was cleared with propylene oxide for $45 \mathrm{~min}$, infiltrated with a $50 \%$ propylene oxide:resin solution for $2-3 \mathrm{~h}$, before finally infiltrating the tissue with $100 \%$ Emix resin for $2 \mathrm{~h}$. The tissue was then flat embedded and the resin allowed to polymerise for $24 \mathrm{~h}$. The tissue was finally transferred to fresh resin and polymerised in a vacuum oven at $70^{\circ} \mathrm{C}$. For light microscopy, thick sections (c. $2 \mu \mathrm{m}$ ) were cut on an LKB ultramicrotome with glass knives, mounted on glass slides, and stained with toluidine blue. Thin sections (for electron microscopy) were stained with $0.5 \%$ uranyl acetate for $35 \mathrm{~min}$ prior to staining with Reynolds lead citrate stain for 10 min (Reynolds 1963). Sections were examined as soon as possible after staining using an HU12A Hitachi transmission electron microscope. 10-20 independent samples were processed in this way, for each treatment, and the observations recorded in the results are based on sections taken from 5-7 of these.

\section{Results}

Structural changes associated with adventitious shoot regeneration from morphogenic leaf explants

Freshly isolated leaf explants had the typical profile of a mature leaf; consisting of an upper 
and lower epidermis, a palisade layer one cell thick and spongy mesophyll layer several cells deep (Fig. 1a). The mesophyll cells contained a large central vacuole with chloroplasts arranged periferally in a marginal layer of cytoplasm (Fig. 1b). The chloroplasts contained a well developed internal membrane system. Grana stacking and membrane appression were evident (Fig. 1c). Mitochondria were also observed throughout the cytoplasm. Leaf explants were examined after
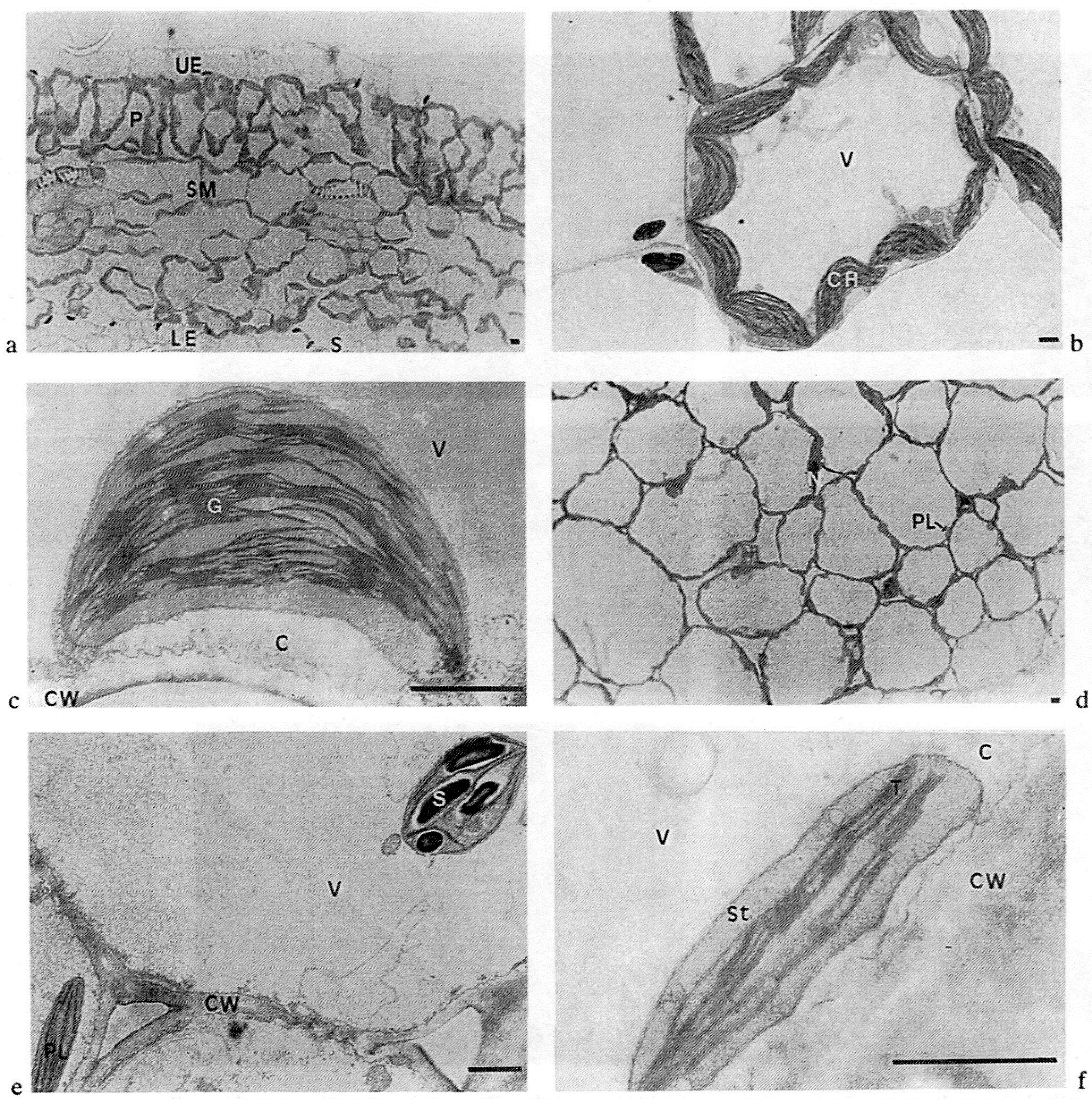

Fig. 1. Structure of cells in leaf explants and pieces excised from leaf strips incubated for 8 weeks on regeneration medium. (a) Light micrograph showing a transverse section through a freshly isolated leaf explant $(\times 1,095)$. (b) Ultrastructure of a spongy mesophyll cell in a freshly isolated explant $(\times 2,555)$. (c) Uitrastructure of a chloroplast in a spongy mesophyll cell $(\times 13,870)$. $(d)$ Light micrograph of a section through a leaf explant after 8 weeks on shoot regeneration medium $(\times 0,730)$. $(e)$ Ultrastructure of same material as $\mathrm{d}(\times 7,300)$. $(f)$ Ultrastructure of a plastid from a leaf explant on shoot regeneration medium $(\times 21,900)$. UEE upper epidermis, P palisade cell, SM spongy mesophyll cell, LE lower epidermis, S stroma, CH chloroplast, V vacuole, G granum, C cytoplasm, CW cell wall, PL plastid, $\mathrm{N}$ nucleus, $\mathrm{S}$ starch grain, St stroma, $\mathrm{T}$ thylakoids. Bars $=1 \mu \mathrm{m}$. 
two months in culture on a shoot inducing medium. Multiple small, adventitious shoots were produced mainly from the cut surfaces of the leaf explants. Small pieces, consisting of the original leaf material, as well as a developing shoot were excised from these explants. Excision was carried out as soon as the shoot nodules appeared, so that they could be examined at as
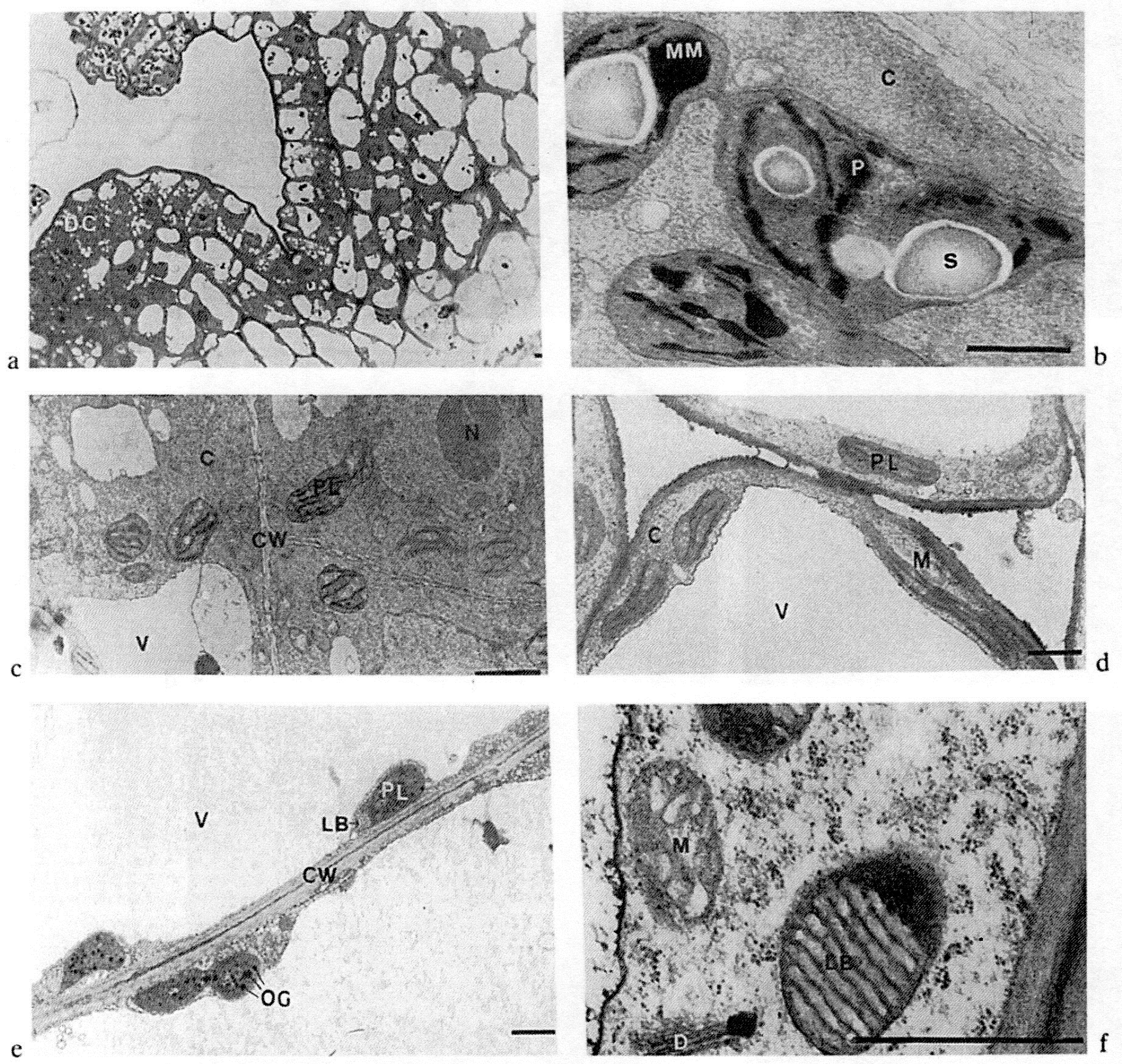

Fig. 2. Structure of cells during early stages of adventitious shoot initiation and the effects of streptomycin on explant cells. (a) Light mictograph of a section through areas of cell division, thought to constitute shoot primordia, which develop at cut surfaces of leaf explants after 8 weeks on regeneration medium $(\times 0,730)$. (b) Ultrastructure of cells in areas of cell division illustrated in $a(\times 13,140)$. (c) Ultrastructure of cells in succeeding layers below $b(\times 7,300)$. (d) Ultrastructure of cells in a more developed adventitious shoot $(\times 7,300)$. (e) Ultrastructure of cells in leaf explants after 8 weeks on shoot regeneration medium in the presence of $500 \mathrm{mg} \mathrm{I}^{-1}$ streptomycin sulphate $(\times 5,475)$. $(f)$ A detail of a cell from the same tissue showing the layered bodies present in the plastids $(\times 29,200)$. DC dividing cells, $M$ mitochondrion, $P$ proplastid, $M M$ membranous material, $O G$ osmiophilic globules, LB layered body, D dictyosome (other designations are as in legend for Plate 1 ). Bars $=1 \mu \mathrm{m}$. 
early a stage as possible. When these explants were examined microscopically, the typical leaf profile was not longer evident and the original leaf material consisted of large vacuolated parenchymatous cells (Fig. 1d). There appears to have been a loss of dermal cell layers and specialized cells. At the ultrastructural level there was a reduction in the amount of granal stacking within the chloroplasts and in some cells the chloroplasts contained starch grains (Fig. 1e). In these chloroplasts there was retention of the stroma thylakoids while the grana were almost completely lost (Fig. 1f). The mitochonria in these cells (not shown) appeared normal.

Based on light microscopy, meristematic areas of cell division were observed which were thought to correspond to the shoot-forming tissues which had developed at the cut surfaces of the leaf material (Fig. 2a). De novo reorganization of the parenchymatous tissue seems to occur initially in the outermost layer of cells. These cells were smaller, less vacuolated and contained densely staining cytoplasm. At the ultrastructural level, irregularly shaped proplastid-like structures were observed within these cells. The outermost layer of cells contained plastids with densely staining material which appeared to be membranous (Fig. 2b). The succeeding cell layers contained plastids which were less densely stained and it could be seen that grana were completely absent from these plastids although parallel rows of stroma thylakoids were observed (Fig. 2c). Many small vacuoles were also present in contrast to the large vacuolated parenchymatous cells in the adjacent leaf tissue. Starch grains were present in the plastids. Mitochondria were also evident throughout the cytoplasm.

In more developed shoot nodules, shoot primordia and vascular tissue were apparent. Mesophyll-like cells were also observed with large central vacuoles and periferally arranged plastids within the marginal cytoplasm. The plastids had a more regular chloroplast shape, but still exhibited poor granal stacking (Fig. 2d). Intercellular spaces were also seen. In young leaf tissue there was little membrane appression, although mature chloroplasts with well developed grana were seen in leaves of adventitiously regenerated plants.
The effects of streptomycin on morphogenic leaf explants

When leaf explants were cultured in the presence of streptomycin, the explants became bleached and shoot production was completely inhibited. When examined microscopically, the typical leaf profile was again absent. The cells were enlarged and irregularly shaped. Intercellular spaces were absent or reduced and the plastids were conspicuous due to a reduction in the cytoplasmic layer. At the ultrastructural level the plastids were irregularly shaped, with a grossly altered morphology (Fig. 2e). Streptomycin impaired thylakoid formation in the chloroplasts and prevented the development of normal grana. Some plastids appeared to have some membraneous material scattered irregularly within the stroma. The most obvious structural change was the presence of large layered bodies within the plastids (Fig. 2f). The appearance of these bodies was altered dependent on the orientation of the plastids within the sections examined. These plastids also contained many small osmiophillic globules which might be associated with the accumulation of protein and other materials which are not assembled into normal thylakoid membranes. Several other types of interplastid bodies were also frequently observed. The fine structure of the mitochondria appeared to be unaltered after streptomycin treatment.

\section{Microscopic examination of streptomycin- resistant shoot primordia}

Streptomycin-resistant nodules were excised as soon as they were visible. It was difficult to excise these small nodules with some of the original leaf material still attached, as the nodules tended to fragment off during excision. As a result, it was not possible to obtain preparations within which the resistant and sensitive tissuc could be contrasted. Microscopic examination revealed that these putative streptomycinresistant nodules were morphologically similar to those formed in the absence of streptomycin except for the presence in many cells (Fig. 3a) of large starch grains within the chloroplasts, which were obvious even in the light microscope. These 

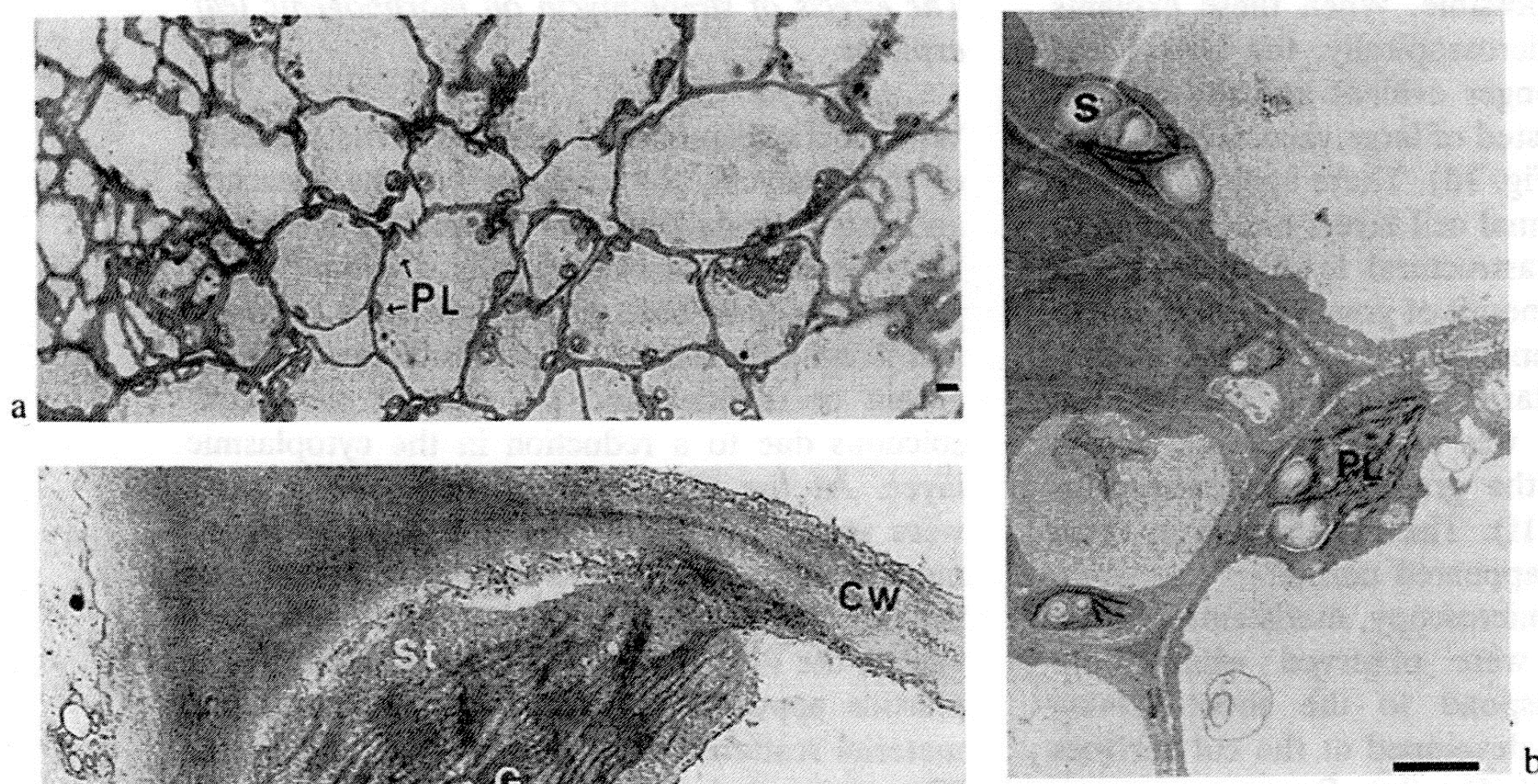

b
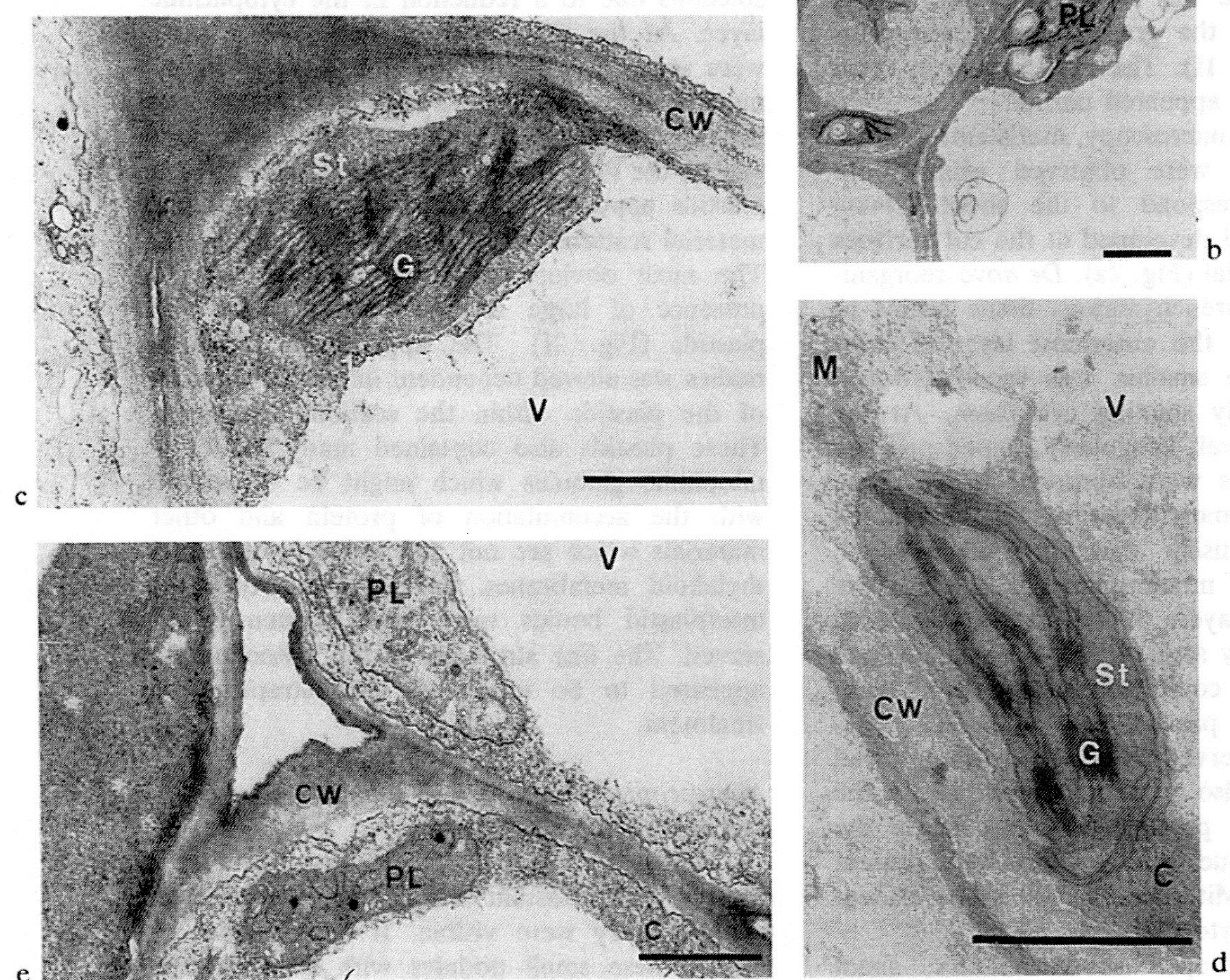

Fig. 3. Structure of cells in streptomycin resistant structures and chlorophyll deficient mutants. (a) Light micrograph of cells in a streptomycin resistant nodule developing from a mutagenised leaf strip, after 8 weeks on shoot regeneration medium in the presence of $500 \mathrm{mg} \mathrm{t}^{-1}$ streptomycin sulphate $(\times 1,920)$. $(b, c)$ Ultrastructure of cells in the same tissue $(\times 9,600$ and $\times 24,000$ respectively). (d) Ultrastructure of cells in adventitious shoots of a previously selected resistant mutant, developing from a leaf explant on streptomycin containing medium $(\times 28,800)$. (e) Ultrastructure of cells in a section through the original leaf tissue of a chlorophyll deficient leaf explant after 8 weeks on a shoot regeneration medium $(\times 16,320)$. Designations are as in legends for plates 1 and 2 . Bars $=1 \mu \mathrm{m}$.

cells contained plastids with reduced thylakoid formation but the starch grains, which were more numerous than those observed in control shoot primordia (Fig. 2b) distorted the parallel arrangement of stroma lamella (Fig. 3b). Other cells contained normal chloroplasts (Fig. 3c), and 
plastids damaged by streptomycin (as in Figs $2 \mathrm{e}$, 2f) were absent, i.e. there were no cells with a mixture of resistant and sensitive plastid types.

Leaf explants from streptomycin-resistant plants which had been isolated after treatment with the mutagen and had been maintained for several months on vitamin- and hormone-free medium containing streptomycin were examined at the ultrastructural level after two months on a shoot inducing medium, both in the presence and absence of streptomycin. Under both conditions, adventitious shoots were produced which were normal in appearance when examined microscopically. In the presence of streptomycin, grana and stroma lamellae were observed in the plastids within the newly produced nodules (Fig. 3d).

Microscopic examination of chlorophyll-deficient mutants

Chlorophyll-deficient mutants have also been obtained using morphogenic leaf explants of $L$. peruvianum following NMU-treatment. Four of these lines have been maintained in culture and in the present investigation, leaf pieces were excised and incubated on a shoot-inducing medium. After two months, adventitious shoots were produced and these were examined microscopically. The tissue and cell structure was similar to that observed in control plants except that the plastids were altered at the ultrastructural level. The plastids in both the original leaf tissue and the newly produced nodules completely lacked thylakoid lamella and grana. Small vesicles were present in the stroma and other larger intraplastid-bodies were also observed. Some small plastoglobuli (or osmiophilic globules) were also seen in some of the plastids (Fig. 3e).

\section{Discussion}

Shoot primordia developing on leaf explants were readily identified as meristematic tissue consisting of small cells containing several small vacuoles. The plastids in these cells were poorly developed with reduced thylakoids and an accumulation of osmiophilic droplets, which may be degradative products of the thylakoid system (Thomas \& Rose 1983). Small starch grains were present in these pro-plastid like plastids but were absent from the plastids seen in the cells of regenerated shoots. Similar changes at both the light and ultrastructural level were reported by Ross et al. (1973) as meristemoid areas develop from tobacco callus. They also observed large amounts of starch present in cells in the early stages of meristemoid development which disappear completely during subsequent development, and have suggested that accumulated starch provides a readily available reserve source of energy for meristemoid cells.

Streptomycin completely inhibited adventitious shoot regeneration from leaf explants of $L$. peruvianum. When examined microscopically, the cells appeared enlarged and irregularly shaped while, at the ultrastructural level, streptomycin prevented the development of normal thylakoid membranes and grana, as has previously been found in tobacco (Maliga et al. 1975). These authors did not, however observe the large layered bodies found in the present study.

Toyama (1972) observed that streptomycin blocked the transformation of prolamellar bodies of tomato cotyledonary cells into normal chloroplasts, in the light, and that 'reacted prolamellar bodies', similar to the layered bodies observed here, persisted. He suggested that the formation of prolamellar bodies may depend on cytoplasmic protein synthesis, whereas functional stroma-and grana-lamellae depend on protein synthesis within the plastids.

The ultrastructure of plastids in freshly emergent streptomycin resistant shoot primordia, on streptomycin containing medium, did not differ greatly from that of plastids in shoot primordia, of sensitive or resistant tissue, in the absence of streptomycin. The adventitious shoots, which developed subsequently, appeared to have a normal cell structure and contained differentiated chloroplasts. By comparison, leaves of the SR1 (streptomycin resistant) mutant of tobacco (Maliga et al. 1975) did have slightly impaired chloroplast development in the presence of streptomycin, with grana containing only $2-3$ thylakoids.

In the present work the mitochondria appeared completely normal in all tissues. This 
observation is consistent with the suggestion (Umiel 1979) that there is differential sensitivity of the two organelles to streptomycin. Maliga et al. (1975), however did observe damaged mitochondria in streptomycin treated tobacco leaf tissue, although the streptomycin resistant mutant (SR1) had intact mitochondria. Abnormal mitochondria, with defective cristae, were also found in streptomycin treated tobacco seedlings (Zamski \& Umiel 1982) and tomato plants (Von Dobel 1963). It appears that $L$. peruvianum mitochondria have a greater innate resistance to streptomycin than these related species.

Chlorophyll-deficient mutants contained plastids completely lacking thylakoid membranes, although some small vesicles and other larger interplastid-bodies were present in the stroma.

Cells containing a mixture of resistant and sensitive plastids were not observed in any of the tissue sections examined. This attests to the efficiency of the use of antibiotics to channel plastid segregation, an observation also made by Moll et al. (1990) who showed the importance of maintaining a selection pressure on each plastome (streptomycin and lincomycin resistance) to maintain a heteroplastidic state in somatic hybrid clones obtained by protoplast fusion in Nicotiana.

\section{Acknowledgement}

We thank Dr. Sheila McNally and the staff of the Electron Microscopy Unit, Trinity College, Dublin, for their advice and expert assitance.

\section{References}

Conde MF, Boynton JE, Gillham NW, Harris EH, Tingle CL \& Wang WL (1975) Chloroplast genes in Chlamydomonas affecting organelle ribosomes. Genetic and biochemical analysis of antibiotic-resistant mutants at several gene loci. Mol. Gen. Genet. 140: 183-220

Dix PJ, Joo F \& Maliga P (1977) A cell line of Nicotiana sylvestris with resistance to kanamycin and streptomycin. Mol. Gen. Genet. 157: 285-280

Dix PJ, McKinley CP \& McCabe PF (1990) Antibiotic resistant mutants of Solanum nigrum. In: Nijkamp HJJ, Van der Plas LHW \& Van Aartrijk J (Ed) Progress in Plant Cellular and Molecular Biology (pp 169-174). Kluwer Academic Publishers, Dordrecht, Boston, London
Etzold T, Fritz C, Schell J \& Schreier P (1987) A point mutation in the chloroplast 16S rRNA gene of a streptomycin resistant Nicotiana tabacum. FEBS Lett. 219: 343346

Fluhr R, Aviv D, Galun E \& Edelman M (1985) Efficient induction and selection of chloroplast encoded antibiotic resistant mutants in Nicotiana. Proc. Natl. Acad. Sci. USA 82: $1485-1489$

Fromm H, Galun E \& Edelman M (1989) A novel site for streptomycin resistance in the '530 loop' of chloroplast $16 \mathrm{~S}$ ribosomal RNA Plant Mol. Biol. 12: 499-505

Galili S, Fromm H, Aviv D, Edelman M \& Galun E (1989) Ribosomal protein $\$ 12$ as a site for streptomycin resistance in Nicotiana chloroplasts. Mol. Gen Genet. 218: 289-292

Hamill JD, Ahuja PS, Davey MR \& Cocking EC (1986) Protoplast derived streptomycin resistant plants of the large forage legume Onobrychis viciifolia Scop (sainfoin). Plant Cell Rep. 5: 439-441

Hirai A, Akada S \& Suguira S (1989) In Applications of Plant Cell and Tissue Culture Ciba Foundation Symposium 137 (pp 113-122)

Jansen CE, Snel EAM, Akerboom MJE, Nijkamp HJJ \& Hille J (1990) Induction of streptomycin resistance in the wild tomato Lycopersicon peruvianum. Mol. Gen. Genet. 220: $261-268$

Maliga P, Szidonia-Breznovits A \& Marton L (1973) Streptomycin resistant plants from callus cultures of haploid tobacco. Nature New Biol. 244: 29-30

Maliga P, Szidonia-Breznovits A, Marton L \& Joo F (1975) Non-mendelian streptomycin resistant tobacco mutant with altered chloroplasts and mitochondria. Nature 255: 401402

McCabe PF, Timmons AM \& Dix PJ (1989) A simple procedure for the isolation of streptomycin-resistant plants in the Solanaceae. Mol. Gen. Genet. 216: 132-137

McCabe PF, Cséplö A, Timmons AM \& Dix PJ (1990) Selection of chloroplast mutants. In: Pollard JW \& Walker JW (Eds) Methods in Molecular Biology. Plant Cell \& Tissue Culture, Vol 6 (pp 469-476). Humana Press Clifton, New Jersey

Medgyesy P (1990) Selection and analysis of cytoplasmic hybrids In: Dix PJ (Ed) Plant Cell Line Selection (pp 287-316). VCH Publishers, Weinheim

Moll B, Polsby L \& Maliga P (1990) Streptomycin and lincomycin resistances are selective plastid markers in cultured Nicotiana cells. Mol. Gen. Genet. 221: 245-250

Murashige T \& Skoog F (1962) A revised medium for rapid growth and bioassays with tobacco tissue cultures. Physiol. Plant. 15: 473-497

Reynolds ES (1963) The use of lead citrate at high $\mathrm{pH}$ as an electron-opaque stain in electron microscopy. J. Cell Biol. 17: 208-212

Ross MK, Thorpe TA \& Costerton JM (1973) Ultrastructural aspects of shoot initiation in tobacco callus cultures. Am. J. Bot. 60: 788-795

Thomas MR \& Rose RJ (1983) Plastid numbers and plastid structural changes associated with tobacco mesophyll protoplast culture and plant generation. Planta 158: 329338

Toyama S (1972) Electron microscope studies on the mor- 
phogenesis of plastids. VII. Effects of streptomycin on the development of plastids in tomato cotyledon. Bot. Mag., Tokyo 85: 89-103

Umiel N (1979) Streptomycin resistance in tobacco. III. A test on germinating seedlings indicates cytoplasmic inheritance in the St-FL701 mutant Z. Pflanzenphysiol 92: 294301

Von Dobel P (1963) Untersuchung der wirkung von strep- tomycin-chloramphenicol- und 2-thiouracil-behandlung arof die plastidenenturicklung von Lycopersicon esculentum Miller. Biologisches Zentralblatt 3: 275-295

Zamski E \& Umiel N (1982) Streptomycin resistance in tobacco. IV. Effects of the drug on the ultrastructure of plastids and mitochondria in cotyledons of germinating seedlings Z. Pflanzenphysiol 105: 143-148. 